\title{
ThE Professor AND THE WORKER: USING BRAZIL TO BETTER UNDERSTAND LATIN AMERICA'S PLURAL LEFT ${ }^{1}$
}

John D. French

The decade following Hugo Chávez's 1998 election in Venezuela has seen left wing leaders reach the presidencies of a multitude of South American and Central American governments: Hugo Chávez, Lula, Tabaré Vázquez, Evo Morales, Rafael Correa, Daniel Ortega, Fernando Lugo, and, most recently, Mauricio Funes in El Salvador. This marks a dramatic political shift in the region's politics after three decades that included dictatorships, neoliberal restructuring, and a fragile but real process of democratization. Contemplating this turn to the left, Max Cameron, Eric Hershberg, and Jon Beasley-Murray asked in 2009: how are we to understand the "diverse parties, movements, and leaders of the Latin American Left" who have now risen to power? Introducing a Third World Quarterly special issue, they emphatically insist that we must think in terms of "left turns in the plural" that stem from "a multiplicity of disparate efforts" and currents (10).

1. Thanks are due to Bret Gustafson and Mabel Moraña for bringing together a stellar interdisciplinary group of Latin Americanists for the stimulating South-byMidwest II Symposium on "Rethinking Intellectuals in Latin America" at Washington University in St. Louis on November 7-8, 2008. Their kind invitation allowed me to deepen my thinking on key issues that began at a May 2007 conference on "Political

Imaginaries in Latin America: Reverberations on the Contemporary Left" sponsored by the Latin American programs of Indiana University and the University of Michigan. 
As they note, the new leftist governments are "as heterogeneous in their politics as they are in their policies" while sharing a marked distance, in all their diversity, from North Atlantic liberalism. They specifically reject efforts "to identify and differentiate [left wing] political projects through dichotomies" $(320,323-5,329)$ such as "social democratic" or "populist," which contrasts with Mexican intellectual Jorge Castaneda who emphatically defends "the adequacy of a dichotomous classification for the Latin American Left" in his coedited 2008 collection entitled Leftovers: Tales of the Latin American Left (Castañeda and Morales, 10). ${ }^{2}$

Nor do Cameron, Hershberg, and Beasley-Murray present the rise of the Lefts in Latin America as inevitable responses to, backlashes against, or repudiations of, neoliberalism. As I argued about Brazil in a 2005 article, the election of Lula in 2002 "was a defeat for neoliberalism and the Washington policy consensus of 1989, but the mass popular vote for Lula was not a conscious repudiation of those policies. Thus the election of Lula was not, as some have proclaimed, a vote for an alternative to neoliberalism" (French and Fortes). More broadly, we might heed similar warnings from James Dunkerley in 2007 against "rhetorical" explanations of the rise of Evo Morales based on "a model of dichotomous relations: international neoliberals v. exploited nationals; whites v. Indians; oligarchs v. subalterns; global models v. local experiences." Such generalizations, he insisted, are yet another indication of "an evident weakness of the Left when it indiscriminately deploys the term 'neoliberal model' as if that were everywhere a beast of self-evident characteristics." Emphasizing neoliberalisms in the plural, Bolivianist geographer Thomas Perrault has correctly emphasized that Latin America has experienced no "single, unitary, monolithic neoliberalism; there are, rather multiple, often contradictory neoliberalisms" (emphasis added) that can "best be thought of not as an end product, but as a variegated and highly contested process riven with internal contradictions." 3

2. Castańeda's 2006 article in Foreign Affairs, which has proven influential in the Washington-New York corridor, championed what he called a "good" social democratic Left versus a "bad" populist Left. See French ("Understanding") for a detailed and wide-ranging critique.

3. I would go further and add that neoliberalism also needs to be understood as a utopia constituted by both a political and economic imaginary; indeed, several 
This chapter places the upward trajectory of the Brazilian Left over the past thirty-five years of this century into regional perspective. If we are to understand the amazing success of the Brazilian Left that has thrived under the penumbra of Lula and his Workers' Party (PT), we must attend to the Left's trajectory since the late 1970s, its moment of maximal unity in the struggles against the military regime that ruled from 1964-1985. A contrast is drawn between the two historic leaders of the Brazilian Left of the 1970s - Fernando Henrique Cardoso (the professor) and Lula (the worker) - as exemplifying the fraught relationship between the intelligentsia and the popular classes. Over the following decades, they would diverge to the point in the 1990s where FHC was the presidential architect of Brazilian neoliberalism and Lula was its most visible opponent. These developments, it argues, are directly connected to the importance of linguistic and cultural capital as markers of distinction in Brazil, a society riven by hierarchies of class, education, color, gender, and origin. It then explores the relevance of this division, as well as class and generational identification, to Lula's triumphant reelection in 2006, despite dissent among important leftist sectors. The chapter ends by placing the Brazilian case into a broader regional perspective through a comparison with the trajectory of the Chilean and Peruvian Lefts.

The Brazilian Left in Regional Perspective from 1980 to 2002

To talk about a rise, resurgence, or reinvention of the Left raises the issue of the point of reference against which we are asked to judge the present. The relevant historical pivot can be found in the dramatic struggles that unified so much of Latin America in 19791980, among them the triumph of the Nicaraguan Revolution, the revolutionary explosions in Guatemala and El Salvador, and the strikes against foreign multinationals and the Brazilian military regime that originated in the industrial suburbs of São Paulo. The unity that marked this historical conjuncture can be clearly seen in the gathering of

scholars have noted that it was the political reforms associated with neoliberalism in Latin America that opened doors (inadvertently) for the success of the very forces that are currently repudiating the word, the ideal, and the outcomes. See also Jan French. 
70,000 metalworkers in the Vila Euclides stadium in São Bernardo do Campo six days after El Salvadoran Archbishop Oscar Romero was gunned down in 1980 by right wing assassins in the cathedral of his nation's capital. The Catholic Bishop of ABC (the municipios of Santo André, São Bernardo do Campo, and Sáo Caetano do Sul), Dom Claudio Hummes, was among those who spoke to the rally where workers had gathered to reaffirm their decision to strike indefinitely starting the next day. As he informed the crowd, the Council of Priests in the diocese had voted to support their movement "until the end, because we believe it is just. And we place the diocese at your service in every way," including the use of our churches, resources, and staff. As the newspaper reported, Bishop Hummes also recalled the assassination of the Archbishop of San Salvador "who died precisely for defending the cause of the people. And this should encourage you all the more," he went on, "to carry your struggle through to the end." Dom Hummes then asked the workers if they would like to pray the "Our Father" with him, and thousands of hands raised stayed upright throughout the prayer as they contemplated the imponderables of what would become the most extraordinary strike in Latin American history: the workers stayed out for forty-one days despite the occupation of the region by the Army, the closing of their union, mass beatings, and the arrest of their leaders - a degree of solidarity achieved without a single picket line! ("E Veio a Greve").

The Latin American and Latin Americanist critical intelligentsia has tended to shy away from this moment of maximal hope and utopian imagining which was followed so quickly by a dystopian regional impact of counter-revolutionary violence, foreign intervention, and defeat. In the recent past, this period has been addressed most explicitly through the study of trauma, memory, mourning and loss (be it in Chile, Argentina, Guatemala, or El Salvador). ${ }^{4}$ Yet such pessimistic appreciations are far less convincing in the Brazilian case. In truth, Brazilians, and those who study Brazil, cannot possibly see the history of the last quarter century in stark and pessimistic terms. ${ }^{5}$

4. As a stimulating example, one might cite the thoughtful and deeply researched recent monographs by Steve Stern (2004, 2006).

5. Even the scale of the violence in Brazil is quite different, even if summed up across the twenty-one years of military rule: no more than four hundred politicallymotivated deaths and disappearances (far fewer than were killed in the Mexican 
It is not that Brazil did not suffer from a dictatorship, which began with U.S. support well before and lasted longer than other Latin American military regimes (1964-1985). Nor is it that tens of millions of Brazilians, of all social classes, did not struggle for democracy or that hundreds of thousands of Brazilians did come to embrace a socialist or revolutionary horizon as part of their struggle to overthrow the rule of the generals. The difference lies in the story of what happened once the country did achieve a democratic electoral system. Despite a post-1982 debt crisis that heralded two "lost" decades in terms of sustained economic growth or substantial social progress, the political story of Brazil's new democracy has not been one of defeat or marginalization of the Left. Instead, what we have seen has been a progressive deepening and broadening of the power of Brazil's various Lefts, and this creativity has been expressed in virtually all realms of national and international life. It was not mere vanity when Lula declared, in 2000 (Da Silva), that "the PT is the most important party of the Left in the world," having grown step by step (not sixteen steps at a time, he adds) to become a powerful and influential example of a Left that succeeded (que deu certo). Nor need we belabor the point by referencing the Brazilian example of internal party pluralism in the PT, the established tradition of inter-party unity on the Left, or the broader social innovations that have given the world "participatory budgeting," ${ }^{6}$ the Movement of Landless Rural Workers (MST), ${ }^{7}$ and the World Social Forum, beacon of the alt-globalization movement. ${ }^{8}$

state of Guerrero alone in the 1970s, and this in the Latin American country that generously hosted one of the largest and most active communities of Latin American exiles during these years). See Comissáo de Familiares de Mortos e Desaparecidos Politicos [Brazil]. Such factual observations about the most extreme form of political repression neither minimizes its significance nor should it be taken to obscure the underlying structural violence and repression characteristic of the Brazilian social order (our access to political and social police records from the 1920s through the $1980 \mathrm{~s}$ is a unique plus for scholars of Brazil). On repression's origin, ubiquity, and impact in urban labor relations, see French ("Proclamando").

6. For good English-language introductions, see Baiocchi $(2003,2005)$ and Nylen.

7. In a recent review ("Review of"), I have offered a succinct analysis of where the MST fits within the Brazilian political scene.

8. For an inside view of the WSF, see the short book by Brazilian petista José Corrêa Leite with assistance from Carolina Gil. 
In a real sense, Brazil stands as the prime example of a combative and democratic organized Left party that combines mass action with institutional participation and electoral success. Thus, the Brazilian trajectory since the 1970 s is quite unlike Venezuela where the organized Left barely recovered from its defeats of the mid1960s; nor does it share a great deal with Bolivia or Peru after the end of military regimes, where the organized Left briefly achieved electoral appeal or even reached power but saw their support collapse while the Left itself was reduced to disunity, dispersal, and loss of influence. And while contemporary Brazil, unlike Argentina, has not experienced a recent social explosion like 2001-02, with its notable creativity and innovation, Brazil in the 1990s did avoid the equivalent of the deeply-rooted hegemony of the extreme neoliberal vogue called menemismo. ${ }^{9}$ In truth, the Brazilian Left could be said to share more with Mexico, especially given the centrality of newlycreated leftist political parties (the PRD in Mexico and the PT in Brazil) whose presidential candidates have been serious electoral contenders since 1988-1989. Of course, this is not to overlook the suigeneris nature of the Mexican case, not to mention the creativity and impact of EZLN, and Brazil's democratization occurred at a very different pace and chronology that was not marked by a tripartite struggle for power between a defined Left, Right, and Center, as in Mexico. And of course, the Brazilian transition itself did not occur within the context of a decaying civilian authoritarian regime that grew out of the aftermath of a social revolution of a sort that Brazil has never experienced during its two centuries of independent existence.

\section{INTELLECTUALS AND WORKERS: DYNAMICS OF INTER-ClASS Relations in Sáo Paulo}

These comparative observations may be seen as a simple reiteration of the basic truth that national histories are distinct, despite our

9. In their interpretation of the slogan "Que se vayan todos?", Ariel C. Armony and Victor Armony advance a provocative hypothesis about how the discourse of Menemismo shaped the imaginary of middle class protests in 2001-02. 
propensity for broad synthetic visions of the region. Yet it is precisely here that the call for a May 2007 workshop in Bloomington, Indiana on "Political Imaginaries in Latin America: Reverberations on the Contemporary Left" asked us to "reexamine the encounters between educated militants (university students, teachers, priests) and subaltern actors in order to shed light on how each understood and transformed the other. Specifically, we seek to understand the cultural contours of the transformative, utopian vision that emerged from these encounters." This avenue of inquiry allows us to understand the upward trajectory of the Brazilian Left over the past three decades. To begin, we need to return to the emblematic images that defined the fight for democracy: the massive stadium rallies of tens of thousands of metalworkers in 1979 and 1980. The emergence of Luis Inácio Lula da Silva, Brazil's current president, as a charismatic personality of unquestioned moral authority was linked to these events when workers repeatedly struck the foreign-owned automobile assembly plants in the suburban $\mathrm{ABC}$ region of Greater Sáo Paulo. These strikes not only "infused extraordinary new energy into the labor movement," as Margaret Keck has written, "but fed the image of an increasingly powerful opposition within civil society to continued military rule" (266).

For many Brazilians, the demonstration of democratic freedom in $A B C$ was so powerful that journalists began to talk about the "Republic of Sáo Bernardo," the one free territory in a country ruled by a feared and stifling dictatorship. Occurring at a remarkable moment of generalized societal discontent with the military regime, even in the dominant class, the unprecedented images of plebiscitary assemblies with tens of thousands of workers was projected and further generalized through a mass media whose struggles to end prior censorship only succeeded as part of the negotiated abertura of the regime in 1979. Thus, people's eyes and imaginations were drawn to the stadium of Vila Euclides in São Bernardo, a municipal facility never referred to by its formal name, the Costa e Silva stadium, in honor of one of Brazil's post- 1964 military dictators. What they saw or imagined was a "Theater of Democracy," with one individual, the thirtyfour year-old Lula, playing the lead; a figure that seemed, with the more they heard, to personify something unimaginably new and democratic. 
Having argued for the central importance of inter-class alliances in my first book on São Paulo's labor history up to $1950,{ }^{10}$ my new book entitled Lula's Politics of Cunning: From Trade Unionism to the Presidency engages directly with the inter-class dialogue as it played itself out between intellectuals and workers from the 1950s through the early 1980s. ${ }^{11}$ In particular, I explore the relationship between "the Worker" (Lula) and "the Professor" Fernando Henrique Cardoso (FHC), the two central figures of the paulista left in the 1970 s who will, by 2010 , have served for sixteen consecutive years as Brazil's presidents (1994-2010). Here, I use as my starting point the multiple attempts by FHC to narrativize his relationship with Lula starting with his two memoirs from 2006, and then dipping back in time to his book-length interviews and biographies from the 1990s. As FHC told an interviewer in 1997, at a point when the president would not have imagined that Lula would ever be his successor (he beat Lula again in 1998): "It's difficult to combat Lula. It's as if I am fighting with my own shadow. I look at him and see my own history." 12

The story of "The Professor and the Worker" is a conflicted one that alerts us to the importance of questions of linguistic capital as markers of social class and a hierarchy of worth. It should not entirely surprise us that FHC, in a recent public talk in Massachusetts, shared a Brazilian joke about George W. and Laura Bush having lunch with Lula during their trip to Brazil; the punch line: none of the three speak Portuguese! Even in his ghostwritten U.S. autobiography, FHC insisted on noting that Lula's "grammar was atrocious," though he graciously says that it is due to Lula's lack of education, and he begrudgingly references his successor's success, in passing, as a matter of having achieved a certain worldwide "celebrity." Indeed, these mildly disdainful comments are not unrelated to $\mathrm{FHC}$ 's putdown, in the same book, of the DOPS police agents who briefly interrogated him in 1976 (his only experience with police repres-

10. "The restoration of democracy in Brazil and elsewhere on the continent in the 1980s highlights the importance of social and political alliances, placing the subject at the top of Latin Americanist research agendas" (282).

11. On the creative intelligentsia's engagement - in both theater and film with workers between 1957 and 1981, see French, ("They Don't Wear BlackTie:"').

12. Cited in Leoni (334). 
sion): "the two thugs . . were barely capable of speaking correct Portuguese." 13

In 2006, FHC reports having first met Lula in his think tank's offices in 1973, when Lula was a lowly first term member of the union diretoria accompanying its President Paulo Vidal. Having published about workers in the early 1960s, when he was director of a newlyformed Center for Industrial and Labor Sociology at USP, FHC reports that he interviewed Lula in 1973 "as I would have any other subject, treating him almost like the subject of a social science experiment." Five years later, he reports being surprised when "Lula quite literally summoned me to meet him in his union office" in São Bernardo do Campo. ${ }^{14}$ In his 2006 Brazilian memoir, he describes this first meeting with Lula at the union's headquarters as "shocking ... in the perceptions of a university professor educated within traditional formalities." (Cardoso and Setti, 84). In the English version, the scene in the union hall is described as intimidating, military-like in atmosphere, and bewildering, with men rudely barking orders. "Finally, I was escorted to a small smoky office where Lula sat, squinting, behind a wooden desk. Several burly men stood menacingly behind him, their arms folded. Lula regarded me for a long moment and then got right down to business" (Cardoso and Winter 136).

This is a central scene for FHC because it is the moment that he receives the support of Lula's union for his candidacy for the Senate (he was elected alternate and assumed the position in 1983 when its holder became Governor of São Paulo). It also opens a period of twenty months in which FHC will be in consistent and ongoing contact with Lula, including participating in a sequence of meetings in 1979 that will lead to the founding of the PT. Serious consideration of "The Professor and the Worker" speaks, in other words, to substantive political questions of continuity and discontinuity in the life of Brazil's single most important and influential Marxist intellectual. Coming from a family of nationalist military men, FHC (b. 1931) was a Communist Party member in his twenties (leaving in 1956), the leader of the influential Marx seminar at USP from 1958-1964, a figure critical of President João 'Jango' Goulart from the Left in 1961-64, and coauthor with

13. Cardoso and Winter $(137,117)$.

14. Cardoso and Winter (Accidental 136). 
Enzo Faletto of the foundational text of the dependencia approach written while in exile in Chile in the mid-1960s. Forcibly retired from USP in 1969, FHC founded the leading opposition think tank CEBRAP where he served as the military regime's most cogent intellectual critic. As Margaret Keck reminds us in her book (The Workers Party 44), FHC was also the first to clearly articulate a credible new opposition strategy, what would today be called "building civil society," and he did so at a discouraging low point of opposition strength in 1973, at the height of the Brazilian "economic miracle" (1968-1974).

What makes FHC's retrospective storytelling all the more compelling is its patently conflicted and contradictory nature, which reflects the difficulties $\mathrm{FHC}$ has experienced in articulating a clear and convincing public answer, even to himself, as to why he did not join Lula in founding the Workers' Party (PT). I explore that first decision by FHC, with its intrinsic drama, because it sheds light on a sequence of subsequent political decisions through which FHC, and the party he founded (PSDB), came to define themselves as the dominant anti-leftist and anti-Lula force across the last twenty years of Brazilian democratic politics (Lula and the PSDB candidate squared off again in 2006). While FHC's decision in 1980 could be interpreted primarily as a question of political philosophy or opposition calculation, FHC's subsequent decisions have moved him further and further down a path towards becoming something different than what he had been. And this is true despite the overlay of verbal markers of "progressiveness" that have always characterized a Brazilian intelligentsia, most often drawn towards power but always desirous of maintaining external validation and internal prestige through proclaimed affiliations with advanced European thought (as with FHC's avowed "social democratic" politics). ${ }^{15}$

In this sense, I offer a surprisingly restrictive geographic answer to the question posed by the organizers of the Bloomington Indiana workshop, while speaking directly to the South by Midwest theme on "Rethinking Intellectuals in Latin America." What is the origin and fate of the political imaginaries of the 1960s and 1970s as they bear on inter-class encounters? The answer is to be found in the capital of Sáo Paulo, a state with thirty five million residents, or, put most baldly and half-jestingly, the story of the past three decades of Brazilian politics can

15. This theme is more fully explored in French (2004). 
be told in terms of what happened in the factories and union in $A B C$ and the halls of the University of São Paulo. Indeed, it's by no means an irrelevant detail that the presidential candidate of the PSDB who Lula defeated in 2002, a one-time Maoist named José Serra, was a former student leader from USP. Not only that, but Serra's election as president of the National Union of Students in 1963 took place in the auditorium of the Santo André metalworkers union hosted by Marcos Andreotti, Lula's Communist trade union predecessor in ABC (French 2010).

In terms of USP (Brazil's equivalent of Harvard, Princeton, and Yale wrapped up in one in terms of prestige), the story can be narrowed further to a tale about the emergence of the new discipline of sociology in a department that produced FHC and a host of radical students who swarmed to São Paulo's factories (whether to study them or colonize them as radical missionaries). Moreover, several generations of scholarship on industrial workers in São Paulo came out of the USP sociology department as successive cohorts of intellectuals passed through various political conjunctures and styles of Marxist analysis between the mid-1950s and the early 1980s. Although the story has many levels of complexity, FHC's role retains its centrality in posing the biggest issues about "us and the other." Interviewed in 1971 by U.S. sociologist Joseph Kahl, FHC was quoted as saying: "The intellectuals in Latin America are important because they are the voices of those who cannot speak for themselves. Unlike the "bureaucrats and politicians' who speak for the state, intellectuals can take a broader view and study poor people and their lives with the aim of discovering: 'What are the real possibilities for change, seen from the point of view of the people without power?"' (179). ${ }^{16} \mathrm{Or}$, as FHC and his ghost writer (Cardoso and Winter 34) put it in his description of Lula's origin for his U.S. readers, what might it have been like to be part of "Brazil's neglected masses"? Or to have been "exposed [as was Lula] to the darkest, most hideous side of Brazilian poverty"?

So let us turn to the rural subaltern world from which tens of millions, including Lula and his family, migrated in search of a better life in the last fifty years. Lula was born in the rural mestiço hinterlands of Pernambuco, one of the historic centers of slaveholding northeastern

16. Kahl chose FHC's quote about the role of the intellectuals as the dedication of the book. 
Brazil. Along with his mother and six of his seven siblings, Lula made a two-week trek southwards on the back of a truck, a ride so uncomfortable that it is known as the pau de arara, or parrot's perch (also the name for a particularly vile and well-established form of torture by Brazilian police). The destination of Lula's family was the jobs and hope that beckoned in São Paulo, where Lula was soon hustling for work in the streets. ${ }^{17}$

Given the significance of education as a marker for social class distinction in Brazil, it is important to contextualize Lula's level of educational achievement. Although Lula went part of a fifth year before dropping out to work, his profile was characteristic of the vast majority of the children of paulista workers who finished most if not all of the four years of primary school. As a researcher, I am lucky that in 1958 a USP sociologist undertook a rich ethnographic study of a primary school in a working class neighborhood in $A B C$, very close to where Lula's family lived at the same time (Pereira). Coming at a moment of stupendous in-migration and population growth, the state's public school system was entering into a downward spiraling crisis. Thus it is very likely that Lula, like the working class kids Luis Pereira studied, got, on average, only three of the four hours of daily instruction mandated by the state. The middle class teachers, who lived far away from the industrial frontier in $\mathrm{ABC}$, felt disdain and prejudice towards their students, most of them the children of migrants, especially those from Minas and the Northeast who were most likely, like Lula, to be mestigo in origin and often black or brown in skin color. The teachers' performance was marked by frequent late arrivals, early departures, and a preference for gossiping together during class time, even putting aside the fact that so many regularly failed to show up to teach. Among the sharpest conflicts with the parents, or at least a tiny minority that was not entirely submissive (egged on by a local populist radio agitator turned politician), was their infliction of corporal punishment, although banned.

The figure of Lula thus stood in a very specific relationship to the racial, regional and educational hierarchies of a changing São Paulo, a city that was ninety percent white and overwhelmingly of European immigrant stock when he first arrived in the early 1950s. Like other

17. For wonderful extended interviews with Lula and his extended family, consult Paraná. 
northeastern migrants, Lula was exposed to a barrage of racialized regionalist abuse, even in the factories where outright racism was common for those who were darker skinned. Indeed, even one of Lula's nicknames was "Baiano," the ubiquitous racist label applied by Paulistas in an effort to stigmatize northeasterners by identifying them with the blackest state of their region, Bahia.

An important element of Lula's emerging appeal involved his ability to project elements of the private and the personal centrally into the public sphere where they gain a different valence. And here, the analysts can draw on the wealth of recent studies on gender and race, because their lives were shaped by the multiple hierarchies of subordination to which Brazil's working people were subjected, and to which they were subjected themselves. This points to a fundamental operative element of a gendered working class praxis and discourse: fazendose respeitar, which can be translated as "making yourself respected," the masculine ideal of imposing oneself in a violently hierarchical world that diminishes you and your manhood. Hence, the power that a discourse of dignity, the resgate da dignidade (the rescue or ransom of dignity), could play; indeed, this discursive element featured powerfully in Lula's discourse from the 1970s until today. And although Lula, like most of his fellow workers, never complained about his personal mistreatment (we're winners not whiners), the experience of a constantly reinforced social and cultural subalternization built up layers of resentment that would, in the end, find expression during the strikes when Lula's most aggressive oratory pledged, "we've been fucked over! We're going to apply the rod (metendo pau) to the bosses and the government! We're going to bring them to their knees!"

The end of the line of this thirty-year duet between USP intellectuals and São Paulo workers comes when a generation of Paulista intellectuals in the late 1970s, along with a handful from earlier generations, finally realized that it was time to listen! ${ }^{18}$ And thus was born a different configuration, and a new and different Left within the middle classes that was more socially open, less hidebound to past hierarchies of distinction, and more open to the idea that one might mix easily with and, more importantly, take leadership from those who do not

18. The landmark work of this leftist rethinking was by a veteran MarxistLeninist New Left intellectual and former exile, Eder Sáder (1941-1988). 
have your degrees, your vocabulary, or your conceptual universe of advanced Marxist thought. The time was coming to an end when a courageous intellectual opponent of the military regime, as late as 1994, famously declared that the choice in the election between FHC and Lula was a no-brainer: "You can vote for Jean Paul Sartre or you can vote for a plumber" (Medeiros 81-82). ${ }^{19}$

And what about the workers, or at least a worker (Lula), who had found his voice and managed to impose himself upon his superiors ("fazendo-se respeitar" in working class terminology)? The answer given would be to deny victimhood and reject the paternalistic condescension of social superiors that still marked FHC and other members of the educated elite in 2006 (indeed, I argue that Lula's heightened sensitivity to any hint of social superiority, once he gained a semblance of power, would play a key role in the unfolding of his subsequent political trajectory). Interviewed by Brazilian Playboy in August 2006, FHC was especially impatient in his criticism of Lula's failure to be a statesman, his lack of dignity, his populist traces. On the question of higher education, he sounded a condemnatory note based on a profoundly old-fashioned but deeply ingrained discourse of social superiority:

You don't have to be a doutor [college graduate] to be the president of the Republic, but you also don't have to be an 'apologist' for ignorance, you needn't preach ignorance. It is better to have information, to have the capacity to form good judgments. I think that Brazilian society has had a certain tolerance with rusticness. The coarser [bruto] the better. . . [But] we live in a civilized society. The ideal is not to be coarse. It is the opposite: it is to be polished ("Fernando Henrique...").

Hope, Identification, and Critique: The Subaltern, the Brazilian LefTs, and the Lula Government

In 2009, the Brazilianist historian Joseph Love (305) asked: "In what ways does the Lula government represent a break with the past?" He began by noting that there are

19. The reference to Sartre is specific to FHC's biography since the young Marxist, having just returned from Paris, served as translator for Sartre and Simone de Beauvoir during their 1960 visit to Sáo Paulo. 
"many unique features of the Lula administration, beginning with the person of the President: $\mathrm{He}$ is the first head of state of a Latin American nation, and one of only a handful in world history, who can claim to be genuine members of the working class. Lula, moreover, has had less formal education than any previous president of Brazil, and is possibly - I emphasize this is conjecture - the least Caucasian president since Nilo Pecanha (1909-10)."

How does the combination of triply stigmatized features - manual labor, lack of education, and symbolic blackening (whether biological or in terms of his northeastern rural background) - play out in the politics of Lula's presidency? The dynamics of this symbolic and generational politics is well-captured by the 2005 documentary "Lula's Brazil: The Management of Hope," shot two years into Lula's first presidential term, by Uruguayan filmmaker Gonzalo Arijón. Elected in 2002, the former trade unionist maintained the neoliberal economic policies he had long opposed, including a fiscal austerity that precluded an immediate increase in social expenditures. By the time this 62minute color film was released, Lula's administration had been devastated by a disgraceful 2005 corruption scandal that led to a barrage of resignations, talk of presidential impeachment, and a major drop in Lula's personal popularity. Rather than rendering the film irrelevant, subsequent developments underline its prescience in capturing the dynamics that led to Lula's stunning re-election in 2006 with $61 \%$ of the valid run-off vote.

So wherein does one find the hope referenced by the film's title? The answer begins to emerge when Chico Whitaker, one of the Brazilian architects of the World Social Forum (WSF), describes the extraordinary hope at Lula's 2003 inauguration as an emotion so powerful as to be painful. Sticking close to Lula's rhetoric, Brazil is described as a nation sundered by violent inequalities with 50 million at the top, fully integrated into the modern capitalist system, and 140 million poor on the bottom. Making use of Lula's campaign ads, Brazil is described not as a poor country but as a country with many poor people, while Lula declares that hunger is the result not of a lack of food but of a lack of shame on the part of those who govern the country.

From this opening, the film retraces Lula's personal trajectory while giving center stage to a dozen humble and eloquent voices from 
that "other Brazil, Lula's Brazil." We hear from the legendary cook at the São Bernardo metalworkers union, where Lula led famous strikes between 1978-1980, as well as from Gilberto dos Santos Souza, a rank-and-file autoworker and PT-member of African descent. Their words provide clear evidence of a powerful sense of identification that is bound up with Lula's origin in the misery of rural Pernambuco, where the film starts, through his migration to the big industrial city of São Paulo and eventual election as the country's first working class president. In Lula's hometown, we meet his cousin Antonio de Mello Ferreira (Lula's anti-hunger program 'is little but it helps,' he says) and accompany health workers who visit the homes of the rural poor to weigh malnourished children as part of the government's Zero Hunger campaign.

The film then moves to São Paulo where we visit squatters (sem teto) who have taken over an abandoned apartment building; families who mix struggle, resignation, and hope for their children while being helped by the government's hunger grants. It is in São Paulo, where so many millions flocked at mid-century, that Lula entered into the lowest part of the top 50 million as a worker in modern industry. After visiting the Daimler-Chrysler factory, we witness an extended barroom discussion among metalworkers who are proud that "one of their own" is running the country and doing so competently despite the predictions of economic disaster before his election. As they weigh their political disappointment against the fragility of hope, they show an acute awareness of the constraints on government action ('he'd like to move quickly but Brazilian voters didn't give him a congressional majority'). We then follow them on a march to Brasília for a minimum wage increase, a demand only partly met; at least this time, Gilson says, the police didn't beat us up and we marched right in to meet the president (we see their hearty exchange of hugs and greetings); besides, Lula promised to make up the rest of the increase before the end of his term.

The film then turns to the rural dimension of the balancing act involved with managing a country. It juxtaposes the critical views of rank-and-file members of the landless workers movement with those of large landowners who, as Whitaker notes, may not be part of Lula's base of support but whose fire power certainly cannot be ignored by the president. One landowner notes that Lula has been reasonable, 
lighting one candle to capitalism and one to socialism, but the government should stop nitpicking because Brazil's economy is sustained by the trade surpluses generated by Brazilian agribusiness; family farming may be a social priority, but it certainly is not an economic one.

The film thus sets up its overall objective: to "gauge the long and bumpy path ahead, a narrow path where hope and economic interests often clash." But is it really possible to "manage" hope under these tight constraints? Here, the film expresses the mature, critical, and balanced judgment that characterized the Brazilian Left in the middle of Lula's first term. We hear Frei Betto, a famous liberation theologian, who explains that one cannot demand results as if Lula had led a revolution when all he did was win an election, which allows at best for the conquest of small parcels of power. While recognizing Lula's limited space for maneuvering, Frei Betto expresses the hope that Lula will know how to conduct the process of change through paths unfamiliar to the Left. So here the film presents us with hope as trust in a politician to whom you are bound deeply, powerfully, and personally. While not abandoning radical desire, the mainstream of Brazil's Left understood that hope is something that cannot be allowed to be lost in a political war of maneuver. In the words of WSF (World Social Forum) leader Candido Grzyowski, Lula's government would do better if it were subject to more pressure from social movements paralyzed in the face of a government protected by its image. Or as Whitaker explains, 'a political victory helps. It is necessary but it is not the answer to our problems. We are all co-responsible for this government' and 'our civil society has to mobilize to confront this monster of inequality, and that development would be welcomed by Lula.'

The film also shows us the anger of disappointed hope when Lula spoke at the January 2005 WSF in Porto Alegre. Having been cheered in 2003, Lula's return is met by steady booing from a significant sector of the stadium audience who call him a "traitor" while chanting "Lula, how sad, a worker governing for the elites." This frustrated leftist hope would turn to rage, after the film was shot, when it became clear in mid-2005 that the PT was "just like any other party" in Brazil's notoriously corrupt political system. Indeed, the defections of voters furthest to the left frustrated Lula's effort to clinch his second term in the 
first round of the election on October 1, 2006. He fell short of the required $50 \%$ because nine million Brazilians, 9.5\% of valid votes, gave their support to two politicians who had exited the PT in harsh protest against the government's inadequacies. ${ }^{20}$

Yet this WSF scene illustrates the complicated dynamics of hope since his critics are demanding an end to hope's betrayal and not all in the stadium are booing. Once Lula gets up to speak, we see the effectiveness of politics as embodied work done with words. In the face of hostile chants, Lula declares that hunger is a political and not a social problem, and criticizes Brazilians for looking northwards to Europe and the United States, and turning its back not only on South America but on Africa. "We are the second largest Black country after Nigeria," the Brazilian president declares, and this takes even his hecklers by surprise. As he reviews Brazil's leadership in the fight against the World Trade Organization, the applause grows as Lula's ends with his trademark "I am from a poor state, Pernambuco, and whoever doesn't die by the age of five is an untiring fighter." When next shown, Lula is on a panel at the Davos World Economic Forum with Bill Gates, where he is unceremoniously cut off after calling for hunger's elimination through an international campaign to be financed by a Tobin tax or a tax on arms sales.

From the depths of disappointment, despair, and anger in 2005, Lula swept the 2006 elections by building on the forms of hope captured in this movie: as identification, concrete benefits, faith, pragmatic calculation, and even hope as betrayal. Having seen Zero Hunger stumble, Lula's replacement Bolsa Familia program was effectively and thoroughly implanted by 2006 , with 11.1 million families receiving its benefits (he swept the poorest regions with $60-85 \%$ of the vote). Even the real value of the minimum wage was increased by a quarter in 2006 compared to 2002 , as promised. And when leftist anger frustrated his first round victory, Lula not only won back those nine million votes, but even gained two and a half million from the first round total of his opponent (Hunter and Power). Lula, the untiring fighter, had once again won and, in his second term, faces the even stiffer challenge of growing hope as well as managing it.

20. For a persuasive analysis of those sectors of the Left that turned against Lula and the PT, see Fortes. 


\section{CONCLUSION}

With a leadership born out of Latin America's most extraordinary strikes in 1979-1980, Lula went on to play a central role in the construction of a new trade union confederation, the CUT with 22 million current members, and founded an entirely new Workers' Party (the PT) that currently has a million members (at the height of the crisis in 2005, 400,000 PT members voted in the internal elections of a new party leadership). As early as 1990 , political scientists of Latin America were well-aware that the PT represents a sui generis political experiment, a unique "mutational experience" in the words of Torcuato di Tella, whose success was likely to have a wide impact. Writing in 1998, the year Chávez was first elected, Kenneth Roberts was attentive to the centrality of the Brazilian Workers' Party experience to understanding the Lefts that were the focus of his monograph Deepening Democracy?: The Modern Left and Social Movements in Chile and Peru.

In characterizing the PT, Roberts judged the party to be what he called an organic rather than electoralist party of the Left, given its emergence from popular insurgencies and social movements and with a leadership drawn directly from them. The result, he suggests, is a "more open, inclusive, and pluralistic" structure with greater democratic participation at the grassroots" (75). In comparing the PT with the Peruvian PUM and the Chilean CP, Roberts notes that these vanguardist formations, despite having incorporating popular sector insurgencies into their ranks, had proven unable to "translate their strength in civil society into sustainable electoral success" after the end of authoritarian rule, unlike the "more 'organic' and heterogeneous Workers Party" in Brazil (271). The bridging of the divide between movement-parties and electorally-successful parties that occurred in Brazil, he suggested, is facilitated when "these organized social constituencies become linked to charismatic leaders with broad appeal, creating a hybrid between the organic model and the populist electoral model." Capable of aggregating "diverse and often atomized popular interests," the challenge is to avoid slipping into top-down "forms of mobilization that engender hierarchical control or displace the autonomous protagonism of organized popular sectors (76)."

The PT was central to the general reflections that Roberts offered on "the project of the Left as Latin America prepares to enter the 
twenty-first century." Contemplating the praxis of Latin American leftist parties under the "transnational neoliberal model of capitalist development," Roberts suggested that whatever emerged from such [leftist] experiments would differ markedly from social democracy as it has traditionally been conceived in Western Europe. More likely than a model of social democracy, with its tradition of centralized social and political organization and top-down reform, would be a process of decentralized bottom-up reform that would potentially build from municipal to national levels of power (276-77)." Having correctly identified the municipal path to power being pioneered during the 1990s by the PT in Porto Alegre, the Frente Amplio in Montevideo, and the PRD in Mexico City, he noted the PT's "conscious efforts to find political mechanisms that build bridges between diverse social movements and community organizations," as with participatory budgeting, while maintaining closer and more organic connection to organized labor. "The combination of effective political articulation and an organic party-society relationship has allowed the Brazilian Left to avoid the radical disjuncture between social movement and electoral strength that one finds in the Left in Peru and Chile, where vanguardist and electoralist orientations have predominated (277-78)." Perhaps, as we speak, the PT and its Latin American counterparts may have lessons to offer the U.S. as it contemplates a turn to the Left in a new post-neoliberal world.

\section{WORKS CITED}

Arujón, Gonzalo. Lula's Brazil: The Management of Hope. Paris: Dissidents \& Arte France. Distributed by First Run/Icarus Films, New York, 2005.

Armony, Ariel C. and Victor Armony. "Indictments, Myths, and Citizen Mobilization in Argentina: A Discourse Analysis." Latin American Politics and Society 47.4 (2004): 40-2, 46.

BarocchI, Gianpaolo, ed. Radicals in Power: The Workers' Party (PT) and Experiments in Urban Democracy in Brazil. London, New York: Zed, 2003.

- Militants and Citizens: The Politics of Participatory Democracy in Porto Alegre. Stanford: Stanford UP, 2005.

Cameron, Maxwell A., Jon Beasley-Murray, and Erick Hershberg. "Latin American Left Turns: An Introduction." Third World Quarterly 30.2 (2009): 319-330. 
Cardoso, Fernando Henrique and Brian Winter. The Accidental President of Brazil: A Memoir. New York: Public Affairs, 2006.

Cardoso, Fernando Henrique, and Ricardo A. Setti. A Arte Da Politica : A História Que Vivi. Rio de Janeiro: Civilizaçāo Brasileira, 2006.

Castaneda, Jorge C. "Latin America's Left Turn." Foreign Affairs 85.3 (2006): 28-43

Castañeda, Jorge, and Marco A. Morales, eds. Leftovers: Tales of the Latin American Left. New York/London: Routledge, 2008.

Comissão de Familiares de Mortos e Desaparecidos Políticos [Brazil]. Dossiê dos Mortos e Desaparecidos Políticos a Partir de 1964. Recife: Companhia Editora de Pernambuco, Governo do Estado de Pernambuco, 1995.

CORRÊA LEITE, José, with assistance from Carolina Gil. World Social Forum: Strategies of Resistance. Translated by Traci Romine. Chicago, IL: Haymarket Books, 2005.

Da SILVA, Luis Inácio 'Lula'. "Lula: Somos O Mais Importante Partido de Izquerda No Mundo." Caros Amigos (2000).

Di Tella, Torcuato S. Latin American Politics: A Theoretical Framework. Austin: U of Texas P, 1990.

Dunkerly, James. "Evo Morales, the 'Two Bolivias' and the Third Bolivian Revolution." Journal of Latin American Studies 39 (2007): 141-42.

"E VeIo a Greve: Uma Decisão Aprovada Por 82 Mil Metalúrgicos." Jornal da Tarde, 31 March 1980.

"Fernando Henrique Cardoso: Uma Conversa Franca com o Ex-Presidente [Entrevista Concedida a Reporter Fernando Barros de Mello e Edson Aran, Diretor de Redação]," Playboy: A Revista do Homen [São Paulo, Brazill, 11 August 2006, 73-91.

FORTES, Alejandro. "In Search of a Post-Neoliberal Paradigm: The Brazilian Left and Lula's Government." International Labor and Working-Class History 75 (2009): 109-25.

FRENCH, Jan Hoffman. "Ethnoracial Identity, Multiculturalism, and Neoliberalism in the Brazilian Northeast." Beyond Neoliberalism in Latin America? Societies and Politics at the Crossroads, Ed. John Burdick, Kenneth M. Roberts, and Philip Oxhorn. New York: Palgrave Macmillan, 2009. 101-113.

FRENCH, John D. "How the Not-So-Powerless Prevail: Industrial Labor Market Demand and the Contours of Militancy in Mid-Twentieth Century São Paulo, Brazil." Hispanic American Historical Review 90.1(2010), 109-142.

-. "Proclamando Direitos, Metendo O Pau, e Lutando Pelos Direitos: A Questão Social Como Caso de Polícia, 1920-1964." Direitos e Justiças No 
Brasil: Ensaios de História Social. Eds. Silvia Hunold Lara and Joseli Mendonça. Campinas: Editora da UNICAMP, 2006. 379-416.

- Drowning in Laws: Labor Law and Brazilian Political Culture. Chapel Hill: U of North Carolina P, 2004.

- "Review of To Inherit the Earth: The Landless Movement and the Struggle for a New Brazil by Angus Wright and Wendy Wolford (Oakland: Food First Books, 2003)." Labor: Studies in Working Class History of the Americas 4.1 (2007): 141-43.

-. "Understanding the Politics of Latin America's Plural Lefts (Chávez/Lula): Social Democracy, Populism, and Convergence on the Path to a Post-Neoliberal World." Third World Quarterly 30.2 (2009): 349-70.

sopital, with remarks upi retrieve material at Thank you!
-. The Brazilian Workers' ABC: Class Conflicts and Alliances in Modern São Paulo. Chapel Hill: U of North Carolina P, 1992.

—. "'They Don't Wear Black-Tie:" Intellectuals and Workers in Modern São Paulo, 1958-1981." International Labor and Working-Class History 59 (2001): 60-80.

French, John D. and Alexandre ForTes. “Another World Is Possible: The Rise of the Brazilian Workers' Party and the Prospects for Lula's Government." Labor: Studies in Working Class History of the Americas 2.3 (2005): 23-4.

HunTer, Wendy and Timothy J. POWER. "Rewarding Lula: Executive Power, Social Policy, and the Brazilian Elections of 2006." Latin American Politics and Society 49.1 (2007): 1-30.

KAHL, Joseph A. Three Latin American Sociologists: Gino Germani, Pablo Gonzales Casanova, Fernando Henrique Cardoso. Rutgers: Transaction Books, 1988.

KECK, Margaret E. "The New Unionism in the Brazilian Transition." Democratizing Brazil: Problems of Transition and Consolidation. Ed. Alfred Stepan. New York: Oxford UP, 1989.

-. The Workers Party and Democratization in Brazil. New Haven: Yale UP, 1992.

Leoni, Brigitte Hersant. Fernando Henrique Cardoso: O Brasil do Possivel. Translated by Dora Rocha. Rio de Janeiro: Editora Nova Fronteira, 1997.

LOVE, Joseph L. "The Lula Government in Historical Perspective." Brazil under Lula: Economy, Politics, and Society under the Worker-President. Ed. Joseph Love and Werner Baer. New York: Palgrave Macmillan, 2009.

Medeiros, Alexandre. Nos Bastidores da Campanha: Luiz Inácio Lula da Silva. Crônica de Um Sonho. Rio de Janeiro: Editora Objetiva, 1994.

NyLEN, William R. Participatory Democracy Versus Elitist Democracy: Lessons from Brazil. New York: Palgrave Macmillan, 2003. 
Paraná, Denise. Lula, O Filho do Brasil. Edição Revista e Ampliada. São Paulo: Editora Perseu Abramo, 2002.

Pereira, Luiz. A Escola Num Area Metropolitana: Crise e Racionalização de Uma Empresa Pública de Serviços. São Paulo: Pioneira, 1965.

Perrault, Thomas. "From the Guerra Del Agua to the Guerra Del Gas: Resource Governance, Neoliberalism, and Popular Protest in Bolivia." Antipode 38.1 (2006): 150-172.

Roberts, Kenneth M. Deepening Democracy?: The Modern Left and Social Movements in Chile and Peru. Stanford: Stanford UP, 1998.

SÁDer, Eder. Quando Novos Personagens Entraram em Cena: Experiências e Lutas dos Trabalhadores Da Grande São Paulo, 1970-1980. Rio de Janeiro: Paz e Terra, 1988.

STERN, Steve. Remembering Pinochet's Chile on the Eve of London 1998: Vol. 1. Durham: Duke UP, 2004.

-. Battling for Hearts and Minds: Memory Struggles in Pinochet's Chile, 1973-1988. Durham: Duke UP, 2006. 


\title{
Rethinking Intellectuals in Latin America
}

\author{
Mabel Moraña and Bret Gustafson (eds.)
}

Iberoamericana - Vervuert 2010 